\author{
遺伝情報をいかに形態学的にとらえるか \\ 一Insitu ハイブリダイゼーション法をはじめとする \\ 分子細胞化学の進歩と内分泌学研究への応用一 \\ 京都府立医科大学第一解剖学教室 \\ 河田光 博
}

\title{
An Attempt to Detect Genetic Information by Means of Molecular Cytochemistry Mitsuhiro Kawata
}

Department of Anatomy, Kyoto Prefectural University of Medicine Kawaramachi-Hirokoji, Kamigyo-ku, Kyoto 602, Japan

In situ hybridization is a histochemical technique that attracts many cell biologists and others interested in developmental biology, virology, genetics and neuroendocrinology. This method gives us the precise localization and identification of individual cells which contain specific nucleic acid sequences, in a similar manner to the immunohistochemistry of cells which have a particular protein. There has been a wide range of applications for this technique. One of the most important and significant applications of in situ hybridization is the demonstration of specific mRNA in particular cells. This is quite valuable in heterogeneous tissue such as that of the hypothalamus with a various types of different cells. The combination with the immunohistochemistry enables us to study the dynamics of peptides or proteins in a certain tissue or cell. In this mini-review the logic and methodology of molecular cytochemistry, particularly in situ hybridization, with its application in the endocrinological field was presented.

Key words : in situ hybridization, gene expression, molecular cytochemistry, mRNA c-fos-jun

は じめ に

——研究は受動的行為ではなく，常に能動的であり，攻撃的ですらあり続ける—

間断なく変化する外部環境に対応してわれわれの生体は, 内部環境を保持しょうとする複雑な調 節機構を有している。このような生物現象は, イオンチャンネルのような分子レベルのものから, 個体として機能表現されるものにいたるまで，すべていわば細胞社会という形態の上に成り立って 
いる。ホルモンをはじめとする細胞間情報伝達物質は, その生化学的特性からタンパク質, 脂質, アミノ酸などに分類される。これらの物質の生成反応や受容機構においては, タンパク質がその中 心的役割を担っているが，タンパク質の種類を決める遺伝情報は DNAの分子構造による。つまり， 三つの塩基の組合せによってタンパク質のアミノ酸配列が決定される訳である。したがって, 塩基 の一次配列構造が，生体において繰り広げられる諸現象の最も根幹的な働きを有していると言って も過言ではない。

内分泌学研究の歴史において, 形態学が果たしてきた役割は測りしれないものがある。遺伝情報 を視覚的にとらえることは, 人類の長年の夢であった。いま, 形態学はその古典的記載主義的立場 から飛び出し，遺伝子や分子の機能に還元して解析されるようになった。本項では, in situ 八イ ブリダイゼーション法を中心に, 分子細胞化学がどのような形で内分泌学研究に応用できるのか述 ベる。

\section{In situ ハイブリダイゼーション法の基本原理}

特定の遺伝子の発現は, 遺伝子を作る DNA の二重ラセン間の水素結合がはずれ, RNA ポリメ ラーゼの作用によって一次転写産物 hn RNA と呼ばれる核酸が5’ $\rightarrow 3$ に向かって転写されること

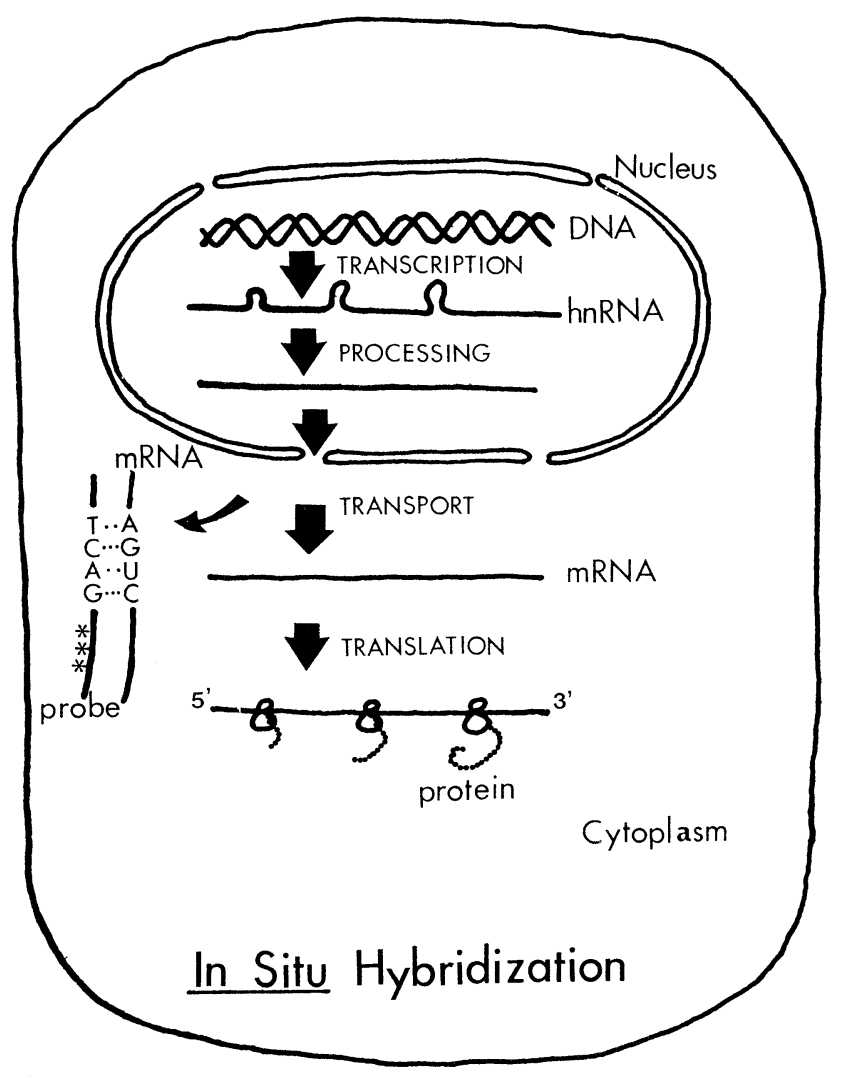

図1. In situ ハイブリダイゼーション法の原理を示す模式図. 
から始をる。生じたhnRNA からアミノ酸をコードしないイントロンの部分が取り除かれたのち， mRNA は核膜孔を通って細胞質内へ移動する。リボゾーム上で mRNA は 5 ’3’ に向かって翻訳 と呼ばれるアミノ酸の縮合を行い, ペプチドやタンパク質が合成されるが, 翻訳を終えた mRNA は直ちに分解される。In situ ハイブリダイゼーションは，これらの過程のなかで，細胞質内で翻 訳が行われるまでの mRNAを，それと相補的塩基配列を有するプローブを用いて検出する（図1）。 mRNA の寿命 (half-life) は mRNA の種類そのものによって異なり, 短いもので30分, 長いもの では約10時間にもおよぶとされる。

\section{In situ ハイブリダイゼーション法の歴史}

In situ ハイブリダイゼーション法とは，細胞内あるいは染色体上の特異的な核酸 (DNA, RNA) の局在を顕微鏡下で明らかにする方法である。つまり，ホモジュネートによる核酸の抽出操作を行 わず，組織細胞形態を保ちながら in situ での核酸分布を可視化する手法である。

この方法は, Pardue と彼女の協同研究者 ${ }^{16)}$ や John らのグループ奋によって, 1969年に発表され， Drosophila とXenopus におけるサテライトDNA や5S リホゾーム遺伝子の細胞内に拈ける分布 が示された。In situ hybridization といら用語は, Pardue らによって案出されたものである ${ }^{16)} 。$ Histohybridization, hybridization histochemistry, 分子雑種法といら語を用いる研究者もいるが, in situhybridization という用語が国際的に最もひろく用いられている。なお，㫛 situは，欧米の 研究者によっても発音法が分かれ，それぞれ半々の学者が [in situ]と [in saitu] と発音している。 私見を述べるならば，やはり前者がより好ましいとおもわれる。

Brahic と Haase ${ }^{1)}$ は, Pardue らが用いた方法に改良を加え, 感度と特異性の高い手法を用いて 細胞に感染したウイルス核酸の同定に成功した。これらの研究はラジオアイソトープ (RI) によっ て標識したプローブを用いて行われたものであるが, Singer と Ward ${ }^{18)}$ は RI を用いない方法を考 案した。彼らは, 用いるプローブをビオチン化し, 酵素組織化学的に標的となるアクチンの核酸の 局在を明らかにした。組織細胞内に存在する特定の mRNAの分布を最初に観察したのは, Roberts $5^{3)}$ である。彼らは, 下垂体前葉におけるプロオピオメラノコルチン (POMC) mRNAを cDNA プローブを用いて形態学的に証明した。その後, 塩基配列をデザインでき, しかも簡便に 作成できる合成オリゴヌクレオチドをプローブに用いる方法が注目を集めるようになり，さまざま な領域でペプチドや受容体 mRNA の検索が進んでいる(1)1121313 。さらに, mRNA とプローブのハイ ブリッド形成の量を切片上で計測し, 画像解析装置を用いて定量的に mRNAの変動をとらえる試 みもなされている7181199。

\section{In situ ハイブリダイゼーション法の特色}

特定の目的とする組織をホモジェナイズし, 抽出した核酸の存在ならびにその定量解析を行ら方 法としてノーザンあるいはサザーンブロット法がある。これらの方法では, 組織の単位体積当りに 対して, 目的とする核酸が一定量以上存在しなければ検出できない。とくに細胞が不均一に分布す るような組織では, 空間的な検索が必要であることは言うまでもない。つまり, 多数の細胞からな る組織において少数の細胞しか遺伝子発現していないような場合では, 上述の手法を用いて目的と する核酸を検出することはきわめて困難である。さらに, どの細胞が, どの程度の量の mRNAを 有しているのかを知ることはきわめて重要な情報であり, in situ ハイブリダイゼーション法の最 
大の特色はこの点にあると言ってもよい。

In situ ハイブリダイゼーション法で用いられるプローブとしては, cDNA，cRNA，オリゴヌク レオチドの三種類がある。cDNA は特異性, cRNA は感度, オリゴヌクレオチドは塩基配列のデ ザインが可能な点など，それぞれの特徵を有する。標識方法としては，RI を用いるものと非 RI 物 質を使用するものに大別される。前者は後者にくらべ高感度であり, 数 pmol の量でも検出が可能 であり，しかもオートラジオグラフィ一法を行えば，切片上での銀粒子数と mRNA 量とに強い相 関性があるため, 細胞レベルで mRNA 量の動態を解析することができる。また後者は, 感度に難 点があるものの細胞内局在性に優れ，複雑な形状を有する細胞での検索に適している。

現在までにホルモンをはじめ, 受容体やイオンチャンネル, 細胞内シングル伝達に関与する二次, 三次メッセンジャ一物質などがつぎつぎとクローニングされ，それらの遺伝子の塩基配列が明らか にされている。そしてこれらの情報は, 整理登録され EMBLや GenBank, DDBJ などのデータベー スとしてまとめられている。合成オリゴヌレオチドをプローブとして使用する場合, このデータベー スを利用して塩基配列をデザインすることが可能である。とくに，遺伝子スーパーファミリー群を 作っているような系では, 類似の mRNA とハイブリッドを形成しないことが必須であり, 相同性 の低い部分を利用して選択的かつ特異的なプローブの作成が，研究成果の精度を上げることになる。

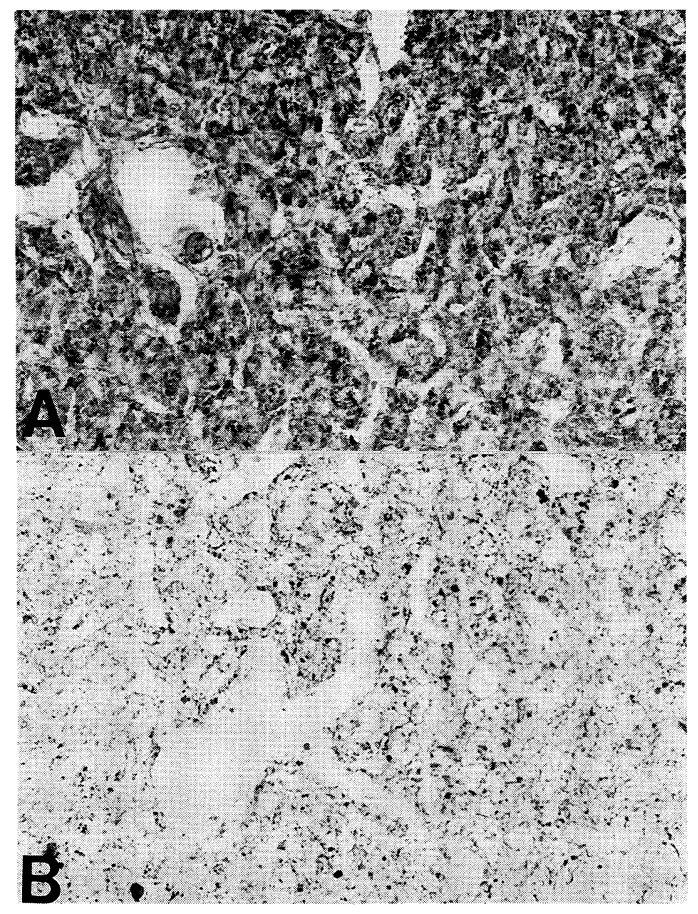

図2. 脱水時における下垂体後葉のバソプレシン免疫反応. 正常 状態 (A) にくらべ脱水時 (B) では著しいバソプレシン免 疫陽性反応の低下がみられる。 


\section{In situ ハイブリダイゼーション法の応用}

\section{1. 免疫組織化学法之の併用 ${ }^{20}$}

免废組織化学法は, 抗原性を有する物質の局在を特異抗体を用いて切片上で検索する方法である。 特定物質の mRNAを in situ ハイブリゼーション法で，またその遺伝子産物であるペプチドやタ ンパク質を免疫組織化学法を用いて証明することによって, 両者の同一組織・細胞内での分布局在 の比較が可能となる。同一切片上でこの二つの異なる方法を施す手法と, 薄切した隣接切片をそれ ぞれ別の手技で染め出す方法が案出されている。

前者の方法では, まず免疫組織化学法を行い, ひき続いて in situ ハイブリダイゼーション法を 施行しなければならない。なぜなら, 逆の手順で行えば, 八イブリダイゼーションの操作によって 抗原性の失活が生じるからである。また免疫組織化学法反応溶液に, RNase の阻害剤を添加して おく必要があることはす論をあたない。

Guitteny ら`は, 薄切された連続切片を用い, in situ ハイブリダイゼーション法と免疫組織化 学法の両者を下垂体後葉ホルモン系への研究に応用した。隣接切接片上でのハイブリダイゼーショ ンシグナルと免疫陽性反応をくらべた結果, 両者に著しい相関性を有する細胞群と, 相関性のみら れない細胞群を認めた。すなわち, ある細胞はシグナル数が多いにもかかわらず免疫反応が弱陽性 であり, 別の細胞はシグナル数が少ないのに反し強陽性の免度反応を呈した。つまり, 特定の刺激

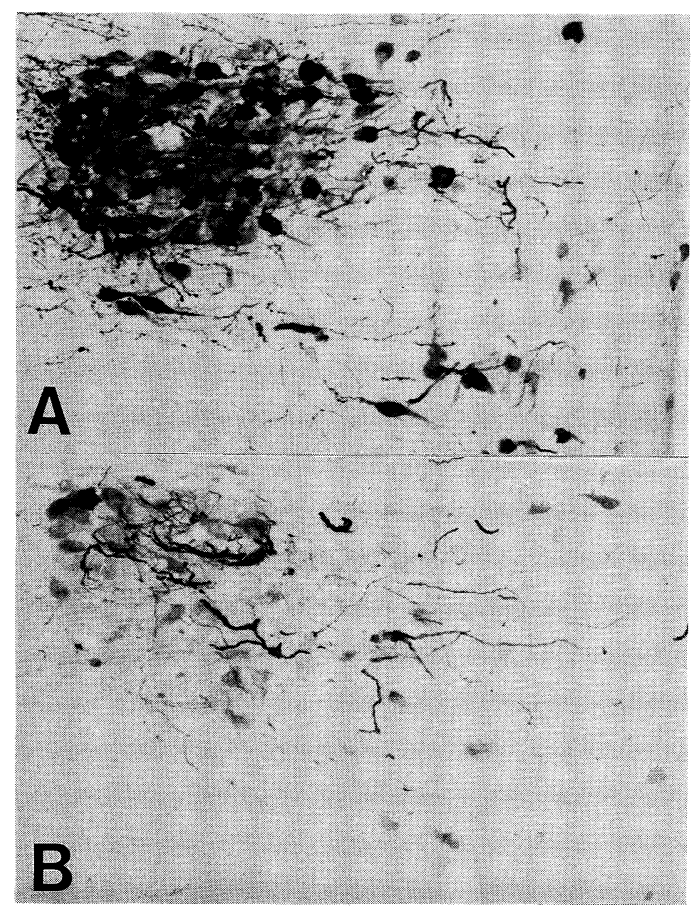

図3. 脱水時における視床下部室傍核のバソプレシン免疫反応. 正常状態 (A) にくらべ脱水時 (B) では著しいバソプレシ ン免疫陽性反応の低下がみられる. 
によってその産生が充進した場合においても，このような神経内分泌系の細胞では終末からの放出 が産生を上まわれば，結果的に免疫組織化学的には反応産物の低下といら形になるのである（図 2 , 3, 4)。このことからも, in situ ハイブリダイゼーション法と免疫組織化学法を組み合わせるこ とによって, より物質の動態変化の機能的側面がとらえられることになる。

\section{2. 異なる物質の mRNA の共存}

免疫組織化学法によって, 複数のホルモンや情報伝達物質が同一細胞内に共存しいることが示さ れている。このことから，mRNAレベルにおいても同様の事象が認められるか否かの検索が行わ れている。たとえ, 物質として同一細胞内に共存していても, 特定の物質を取り込んだ結果として 共存しているのか, あるいは実際に異なる物質が同一細胞内で産生されているのかが問題となるか らである。

Fischer-Colbrie ら²) B）のそれぞれの mRNAの変動を, 自律神経刺激招よびホルモン刺激下で観察した。その結果, エンケファリンとニューロペプチドYの mRNA は，内臟神経刺激によって著しく増加するにもか かわらず, クロモグラニン mRNA には変化がないことかが示された。逆に, 下垂体摘出によって クロモグラニン mRNA は有意に隇少するのに対し, エンケファリンとニューロペプチドYの両者 の mRNA には変化がなかった。

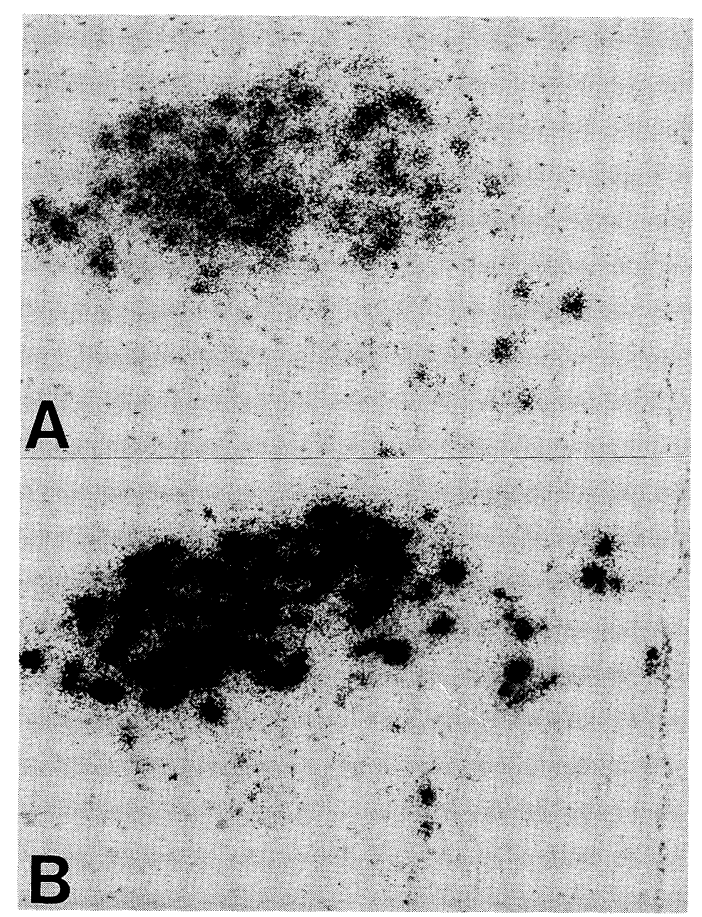

図4. 脱水時における視床下部室傍核のバソプレシン mRNA. 正常状態 (A) にくらべ脱水時 (B) では著しいバソプレシ ン mRNAの増加がみられる. 
ハソプレシンニューロンは，その大細胞性群においてダイノルフィンを共有している。 Sherman ${ }^{17)}$ らは，浸透圧刺激によってバソプレシンとダイノルフィンのそれぞれの前駆体 mRNA の動きを観察し，両者が同時に強調的に変動することを明らかにした。

このように，共存する物質の mRNAの動態はさまざまであり, 現在のところこの調節機構につ いての統一された見解はない。

\section{3. 電子顕微鏡的観察への応用}

In situ ハイブリダイゼーション法を電子顕徽鏡レベルに応用しょうといら試みもさかんに行わ れている。 ${ }^{5)}$ エポキシ樹脂に試料を包埋し，ハイブリダイゼーション反応を行ったのち，超薄切し て電子顕微鏡的に観察する方法が開発された。感度の問題もあり，オートラジオグラフィー法によ る電䫓観察が最も成功している。多くの場合, 特定の物質の mANA は, 予想される部位に限局し て存在している。つまり，粗面小細胞周辺に標識物質の集積が認められている。このほか，核膜周 囲にもシグナルが観察されている。

\section{4. 神経内分泌系における mRNAの輸送}

mRNA が神経細胞の軸索内を輸送されるといら驚くべき知見が多くの研究室で認められてきた ため ${ }^{4)}$ ，本項を設け概説する。

脊椎動物の神経系一神経内分泌細胞も含め一に抒いては，いわばセントラルドグマとして次のこ とが一般的に確立されている。神経細胞体の延長である樹状突起内には，タンパク合成に必要なリ ボゾームや mRNA が認められているが, 軸索は元来, これらの産生物質を輸送する特殊に分化し た突起であるとされてきた。ところが近年，後葉ホルモンのバソプレンやオキシトシンの mRNA が軸索終末の集積部位である下垂体後葉に証明された。視床下部下垂体系を切断したり，軸索内輸 送を阻害するコルヒチンの投与によって，下垂体後葉内の mRNA が消失することから，視床下部 の細胞体で作られた mRNA が軸索内を輸送され，後葉にまで運ばれることが明らかなった。この ことは，神経細胞の極性を考察する上で，きわめて示唆に富んだ事実といえよう。

\section{遺伝子発現調節への c-fos, jun の役割り}

細胞への刺激がどのような形で遺伝子につたえられるのか, 現在のところ三つの様式が明らかに されている ${ }^{15)}$ 。第一は, ステロイドホルモンをはじめとするような脂溶性物質は, 細胞膜を単純拡 散によって通過し, 細胞内の受容体と結合したのち, その複合体が目標となる遺伝子と結合して転 写をおこさせるものである。第二は，二次メッセンジャ一を介するもので，この二次メッセンジャ一 が直接遺伝子の転写を調節するものである。第三は，二次メッセンジャーが核内の特定のガン遺伝 子（c-fos，c-jun）に作用し，転写因子の合成を行った後，この転写因子が再び核内に戻り，目標 となる遺伝子の転写を調節するものである。したがって c-fos p c-jun の発現産物を見れば，あ る特定の遺伝子発現を間接的に証明しらると言えよう。細胞に加えられた刺激は直ちに c-fos と cjun の mRNA の産生となり, 1 2 時間のうちに細胞質中でその翻訳物質をつくり, 再び核内でダ イマーを形成し AP-1結合部位に結合して, 特定の遺伝子の発現をおこさせる（図5）。この FOSJUN の発現タンパクダイマーの半減期も約 2 時間であり, この系は即時型の遺伝子転写調節に関与 していると言える。FOS-JUN はその蛋白の一部がラセン状を呈し，しかもロイシンが規則的に配 
列し，ロイシン・ジッパーと呼ばれ結合している。このダイマーが DNA 上の TGACTCA 部位に 強い結合能を持っていることが近年明らかとなった。このような proto-oncogene は, 二次メッ センジャーと目的遺伝子の間に介在する三次メッセンジャーとして, 近年注目を集めており, これ らの発現タンパクやその mRNAの変動をみることは, 遺伝子発現機構解明の大きな機能形態学的 手がかりとなりらる ${ }^{6}$ 。

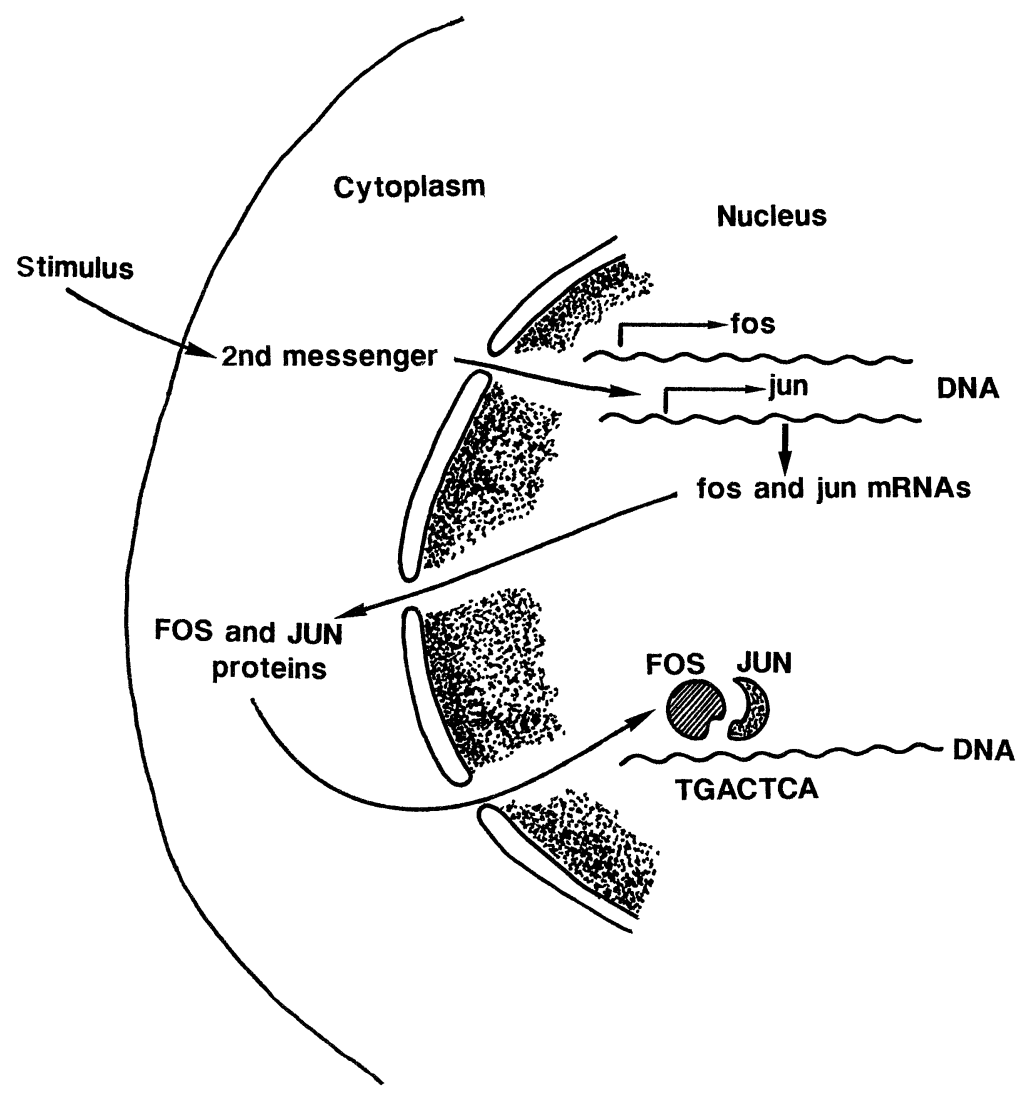

図5. c-fos, jun による遺伝子転写調節を示す模式図.

おわりに

In situ ハイブリダイゼーション法を中心に, 形態学の領域で活性に研究されている項目を概説 した。紙面の都合上, 多くの知見を割愛したが，いままで，“静的”とされてきた形態学に時間と いう“動的”な側面が加えられてきており, 学問のボーダーレス化とあいまって, より本質的な展 開が期待できると言えよう。

文献

1) Brahic M. and Haase A.T.: Detection of viral sequences of low reiteration frequency by 
in situ hybridization. Proc. Natl. Acad. Sci. U.S.A., 75: 6125-6129,

2 ) Fischer-Colbrie R., Iacangelo A. and Eiden L.E.: Neural and humoral factors separately regulate neuropeptide $\mathrm{Y}$, enkephalin, and chromogranin A and B mRNA levels in rat adrenal medulla. Proc. Natl. Acad. Sci. U.S.A., 85: 3240-3244, 1988.

3 ) Gee C.E. and Roberts J.L.: Laboratory methods for in situ hybridization histochemistry: A technique for the study of gene expression in single cells. DNA, 2: 155-161, 1983.

4) Guitteny A.-F., Bohlen P. and Bloch B.: Analysis of vasopressin gene expression by in situ hybridization and immunohistochemistry in semi-thin sections. J. Histochem. Cytochem., 36: 1373-1378, 1988.

5 ) Guitteny A.-F. and Bloch B.: Ultrastructural detection of the vasopressin messenger RNA in the normal and Brattleboro rat. Histochemistry, 92: 277-281, 1989.

6) Hamamura M., Nunez D., Leng G., Emson P.C. and Kiyama H.: c-fos may be a common transcription factor within the hypothalamic neural circuits involved in osmoregulation. Mol. Brain Res. (in press)

7 ) Harbuz M., Russell J.A., Sumner B.E.H., Kawata M. and Lightman S.L.: Rapid changes in the content of proenkephalin $\mathrm{A}$ and corticotrophin releasing hormone mRNAs in the paraventricular nucleus during morphine withdrawal in urethane-anaesthetized rats. Mol. Brain Res., 9: 285-291, 1991.

8 ) John H.A., Birnstiel M.L. and Jones K.W.: RNA-DNA hybrids at the cytological level. Nature, 223: 582-587, 1969.

9) Kawata M., McCabe J.T. and Pfaff D.W.: In situ hybridization histochemistry with oxytocin synthetic oligonucleotide: Strategy for making the probe and its application. Brain Res. Bull., 20: 693-697, 1988.

10) Kawata M., McCabe J.T., Harrington C., Chikaraishi D. and Pfaff D.W.: In situ hybridization analysis of osmotic stimulus-induced changes in ribosomal RNA in rat supraoptic nucleus. J. Comp. Neurol., 270: 528-536, 1988.

11) Kawata M., Yuri K. and Kumamoto K.: In situ hybridization histochemistry with oligodeoxynucleotide probe as a tool for the detection of neuropeptide mRNAs. Acta histochem. Cytochem., 23: 307-325, 1990.

12) Kawata M., Yuri K. and Sano Y.: Localization and regulation of mRNAs in the nervous tissue as revealed by in situ hybridization. Comp. Biochem. Physiol., 98C: $41-50,1991$.

13) Lewis M.E., Sherman T.G. and Watson S.J. : In situ hybridization histochemistry with synthetic oligonucleotides: Strategies and methods. Peptides, 6(Suppl. 2): 75-87, 1985.

14) Mohr E., Fehr S. and Richter D.: Axonal transport of neuropeptide encoding mRNAs within the hypothalamo-hypophyseal tract of rats. EMBO J., 10: 2419-2424, 1991.

15) Morgan J.I. and Curran T.: Stimulus-transcription coupling in neurons: role of 
cellular immediate-early genes. Trends in Neurosci., 12: 459-462, 1989.

16) Pardue M.L. and Gall J.G.: Molecular hybridization of radioactive DNA to the DNA of cytological preparations. Proc. Natl. Acad. Sci. U.S.A., 64: 600-604, 1969.

17) Sherman T.G., McKelvy J.F. and Watson S.J.: Vasopressin mRNA regulation in individual hypothalamic nuclei: a Northern and in situ hybridization analysis. J. Neurosci. 6: 1685-1694, 1986.

18) Singer R.H. and Ward D.C.: Actin gene expression visualized in chicken muscle culture by using in situ hybridization with a biotinated nucleotide analog. Proc. Natl. Acad. Sci. U.S.A., 79: 7331-7335, 1982.

19) Sumner B.E.H., Kawata M. and Russell J.A.: Does acute, intense stimulation of oxytocin neurones in the supraoptic nucleus increase their content of oxytocin mRNA? Brain Res., 489: 283-290, 1989.

20) Watts A.G. and Swanson L.W.: Combination of in situ hybridization with immunohistochemistry and retrograde tract-tracing. In: Conn M, Methods in Neuroscience, vol 1 Gene probes. San Diego: Academic Press, 1989: 127-136. 